\title{
Kepadatan Tetraselmis sp. yang di Kultur pada Media Carboy dengan Nutrien yang Berbeda
}

\section{Density of Tetraselmis sp. Cultured in Carboy Media with Different Nutrients}

\author{
Chelsey Violeta Christya Archadia Cheres ${ }^{1}$, Novia Salmatin ${ }^{1}$, Lailatul lutfiyah ${ }^{2 *}$ \\ ${ }^{1}$ Program Studi Akuakultur, Universitas Airlangga PSDKU Banyuwangi, Jl. Wijaya Kusuma No. \\ 113 Giri, Banyuwangi 68425, Jawa Timur. \\ ${ }^{2}$ Program Studi Akuakultur, Departemen Manajemen Kesehatan Ikan dan Budidaya Perairan, \\ Fakultas Perikanan dan Kelautan, Universitas Airlangga Surabaya. \\ *Email: lailatullutfiyah@fpk.unair.ac.id
}

\begin{abstract}
Abstrak
Pakan merupakan kunci keberhasilan dalam budidaya perikanan, karena berpengaruh terhadap ketahanan dan perkembangan larva. Jenis pakan yang diberikan pada larva ikan yaitu pakan buatan dan pakan alami. Salah satu jenis pakan alami yang digunakan sebagai penambah kebutuhan pakan budidaya adalah fitoplankton jenis Tetraselmis sp,. Sehingga diperlukan adanya penelitian untuk mempelajari, memahami dan mempraktekan secara langsung teknik kultur pakan alami Tetraselmis sp. skala laboatorium. ini dilaksanakan di (BBPBAP) Jepara, Jawa Tengah Desember 2018 - Januari 2019. Teknik kultur terdiri atas beberapa tahapan diantaranya adalah persiapan alat dan bahan, sterilisasi, pembuatan pupuk, persiapan media, penghitungan inokulan, pemberian nutrisi, penebaran bibit dan pemeliharaan. Tetraselmis sp. memiliki empat fase pertumbuhan yang terdiri atas fase adaptasi, eksponensial, stasioner dan kematian. Tetraselmis sp. mengalami kepadatan tertinggi pada hari kesepuluh dengan rata-rata $109,87 \times 10^{4} \mathrm{sel} / \mathrm{ml}$. Hal ini menunjukkan bahwa pertumbuhan Tetraselmis sp. Pasca fase eksponensial, Tetraselmis sp. mengalami fase stasioner selama tiga hari dan selanjutnya menurun hingga kepadatam 65,22 x $10^{4}$ sel/ml pada akhir kultur.
\end{abstract}

Keyword : Tetraselmis, Fitoplankton, Teknik Kultur.

\begin{abstract}
Feed is the key to success in aquaculture, because it affects the resistance and development of larvae. There are two types of feed given to fish, namely artificial feed and natural feed. One type of natural feed that can be used as an enhancer for aquaculture feed needs is Tetraselmis sp.. So that practice is needed to learn, understand and practice directly the Tetraselmis sp. Natural feed culture techniques. laboratory scale. This research was held at the Brackish Water Aquaculture Center (BBPBAP) Jepara, Central Java for 46 days starting on December 17, 2018 until January 31, 2019. The culture technique consists of several stages including the preparation of tools and equipment, sterilization, fertilizer making, media preparation, calculation of inoculants, nutrition, seedling and maintenance. Based on observations for 16 days, Tetraselmis sp. has four growth phases consisting of adaptation, exponential, stationary and death phases. Tetraselmis sp. experienced the highest density on the tenth day with an average of $109.87 \times 104$ cells / ml. This shows that the growth of Tetraselmis sp. long enough than other species. After experiencing the exponential phase, Tetraselmis sp. experienced a stationary phase for 3 days and subsequently decreased density to reach $65.22 \times 104$ cells/ml on the sixteenth day.
\end{abstract}

Keyword : Tetraselmis, Phytoplankton, Culture Technique 


\section{PENDAHULUAN}

Keberhasilan usaha budidaya perairan didukung oleh empat aspek manajemen yaitu manajemen kualitas air, benih, induk dan manajemen pakan. Manajemen pakan merupakan faktor terpenting dalam budidaya, hal ini karena pakan faktor pembatas bagi organisme yang dibudidayakan (Sari dan Manan, 2012). Jenis pakan yang dapat diberikan pada ikan terdiri dari pakan alami dan buatan. Pakan yang baik adalah pakan yang mampu memenuhi kebutuhan nutrisi biota budidaya untuk tumbuh dan berkembang. Pakan merupakan kunci keberhasilan dalam budidaya perikanan, karena berpengaruh terhadap ketahanan dan perkembangan larva. Kegiatan budidaya perikanan laut yang berkembang saat ini harus diimbangi dengan ketersediaan larva atau benih ikan yang memadai, baik dari segi jumlah, mutu dan keberlanjutannya.

Salah satu faktor yang menyebabkan terhambatnya pengadaan larva tersebut adalah sulitnya menyediakan pakan dengan kualitas baik, terutama pakan alami yaitu fitoplankton dan zooplankton. Sejalan dengan pesatnya budidaya perikanan di Indonesia, peran pakan alami bagi usaha pembenihan ikan sangat mendukung untuk budidaya (Anggraeni, 2016). Menurut Basri (2013) pakan alami mempunyai kandungan gizi yang lengkap, mudah dicerna dalam saluran pencernaan, tidak menyebabkan penurunan kualitas air dan dapat meningkatkan daya tahan benih ikan terhadap penyakit maupun perubahan kualitas air.

Selain itu, ukuran dari pakan alami yang diperlukan untuk benih ikan harus lebih kecil dari ukuran lebar mulutnya. Pakan alami merupakan pakan yang baik untuk budidaya karena diketahui memiliki kandungan nutrisi jauh lebih banyak dibandingkan dengan pakan buatan dan menjadi sumber nutrisi penting pada stadium awal perkembangan organisme. Saat ini telah banyak dihasilkan pakan buatan untuk larva, namun keberadaan pakan alami tetap dibutuhkan.

Tetraselmis sp. merupakan salah satu jenis pakan alami yang sering digunakan sebagai pakan dan mempunyai nilai gizi yang baik (Supriyantini dkk., 2007). Menurut Isnansetyo dan Kurniastuty (1995) 
bahwa Tetraselmis sp. mengandung protein berkisar $49,75 \%$ dan karbohidrat 19,37\%. Oleh sebab itu, Tetraselmis sp. sangat cocok digunakan sebagai pakan zooplankton dan ikan dalam suatu usaha budidaya. Tujuan dari penelitian ini adalah mengetahui kepadatan Tetraselmis sp. pada masing masing media yang berbeda.

\section{METODE PENELITIAN}

\section{Waktu dan Tempat}

Penelitian ini dilakukan mulai Desember 2018 sampai Februari 2019 di Laboratorium Pakan Hidup Balai Besar Perikanan Budidaya Air Payau (BBPBAP), Jepara, Jawa Tengah.

\section{Materi Penelitian}

Peralatan penelitian

Peralatan yang digunakan selama penelitian terdiri dari: bak tandon air, erlenmeyer, thermometer, refraktometer, $\mathrm{pH}$ meter, mikroskop, object glass, cover glass, pipet tetes, beaker glass dan gelas ukur, mikropipet dan mikrotip, rak kultur berfungsi, lampu TL, selang aerasi dan aerator, autoclave dan oven. Sementara bahan yang digunakan terdiri dari: air laut dan air tawar, pupuk urea, SP36, ZA, $\mathrm{FeCl}_{3}$,
EDTA, Vitamin B12, Alumunium foil, kapas dan kasa, sabun, sedotan, chlorin serta natrium thiosulfat.

\section{Rancangan penelitian}

Penelitian ini menggunakan metode Rancangan acak kelompok (RAK) dengan 4 perlakuan dan 3 ulangan. Perlakuan dalam penelitian ini yaitu penambahan dosis probiotik pada P1: 0,007 ml/1, P2: 0,008 ml/1, P3: 0,009 ml/l, dan P0: control.

\section{Prosedur Kerja}

\section{Persiapan kultur Tetraselmis sp.}

Teknik kultur meliputi persiapan alat dan bahan, sterilisasi, pembuatan pupuk, persiapan media, penghitungan inokulan, pemberian nutrisi, penebaran bibit dan pemeliharaan.

\section{Sterilisasi wadah dan media}

Sterilisasi yang dilakukan meliputi sterilisasi alat (glassware) menggunakan oven pada suhu $150^{\circ} \mathrm{C}$ selama 15 menit dan sterilisasi selang aerasi dengan uap panas pada suhu $100^{\circ} \mathrm{C}$ selama \pm 15 menit. Sementara itu, sterilisasi tip menggunakan autoclave selama \pm 20 menit dengan tekanan 1 atm pada suhu $126^{\circ} \mathrm{C}$.

Selanjutnya, untuk sterilisasi air laut dilakukan dengan 
menambahkan larutan chlorin ditingkatkan untuk meratakan dengan dosis 60 ppm pada air laut yang berada di bak penampungan dan dibiarkan selama 24 jam. Setelah itu, ditambahkan natrium thiosulfat dengan dosis 30 ppm, dengan maksud untuk menghilangkan sisa chlorin yang masih tertinggal di media. Air laut yang digunakan sebagai media kultur disesuaikan dengan syarat tumbuh optimal Tetraselmis $s p$. yakni pada salinitas 30 ppt. Salinitas tersebut diperoleh dengan mengencerkan air laut yang telah disterilkan menggunakan air tawar menurut perhitungan Ruliaty, dkk. (2017). Selanjutnya, media air laut dipindahkan pada toples dan diberi aerasi, hal ini berfungsi sebagai sumber oksigen dan untuk menghomogenkan nutrient.

\section{Pemupukan dan Penanaman inokulan (bibit)}

Pupuk yang digunakan pada kultur memiliki kandungan 100 ppm Urea, 50 ppm SP36, 20 ppm ZA, 1 ppm $\mathrm{FeCl} 3,5$ ppm EDTA, dan 0,01 ppm Vitamin B12. Pemupukan dilakukan pada media kultur dari masing masing wadah dengan dosis $0,05 \mathrm{ml} /$ liter. Selanjutnya, tekanan aerasi nutrisi dan pupuk tersebut. Selanjutnya dilakukan penebaran bibit sesuai dengan perhitungan sebelumnya dan dilanjutkan dengan pemeliharaan kultur. Monitoring kepadatan dan faktor fisika, kimia serta biologi lingkungan dilakukan selama pemeliharaan.

\section{Perhitugan kepadatan}

Setelah sampel diletakkan pada wadah, sampel diberi formalin dengan konsentrasi 4\%. Hal ini bertujuan untuk melumpuhkan Tetraselmis sp. ketika dilakukan penghitungan. Formalin dapat merusak pertumbuhan dan pembelahan sel sehingga menimbulkan kerusakan struktur jaringan tubuh (Rinto, dkk., 2009). Penghitungan bibit Tetraselmis sp, menurut Ruliaty, dkk. (2017) dilakukan menggunakan rumus :

$$
\mathrm{V}_{1} \times \mathrm{N}_{1=} \mathrm{V}_{2} \times \mathrm{S}_{2}
$$

$\mathrm{V}_{1}$ : Volume yang diperlukan

$\mathrm{N}_{1}$ : Kepadatan awal

$\mathrm{V}_{2}$ : Volume akhir

$\mathrm{S}_{2}$ : Kepadatan yang diinginkan

Selanjutnya, perhitungan kepadatan sel Tetraselmis sp, dengan metode small block menggunakan 
Haemocytometer merk Assistant.

Penghitungan sel dilakukan dengan cara menghitung sel yang terdapat dalam setiap kotak, dihitung dari sisi kiri kotak kearah kanan kotak (Satyantini, dkk., 2012).

\section{Analisa Data}

\begin{tabular}{lrr}
\multicolumn{2}{c}{ Data disajikan } & dalam \\
bentuk grafik atau & gambar, \\
selanjutnya dianalisis & secara \\
deskriptif berdasarkan & literatur \\
terkait yang relevan & untuk \\
menentukan pengaruh & waktu \\
kultur dengan tingkat kepadatan & literatur \\
serta dibahas dengan & menarik \\
yang relevan untuk & menalan & \\
kesimpulan
\end{tabular}

\section{HASIL DAN PEMBAHASAN}

Rata - rata kepadatan Tetraselmis $s p$ pada awal pemeliharaan sebesar $9,77 \times 10^{4}$ sel/ml, dan meningkat menjadi 11,77 x $10^{4} \mathrm{sel} / \mathrm{ml}$. Secara keseluruhan, secara signifikan peningkatan kepadatan terjadi pada hari kedua sampai kesepuluh yang rata-rata kepadatan tertinggi sebesar 109,87 x $10^{4} \mathrm{sel} / \mathrm{ml}$. Akan tetapi, setelah periode tersebut kepadatan Tetraselmis sp. mengalami penurunan hingga hari ke enambelas dengan rata-rata kepadatan sebesar
$65,22 \quad$ x $10^{4} \quad$ sel/ml. Kami menemukan bahwa Tetraselmis sp. mengalami fase pertumbuhan sesuai dengan fase fitoplankton pada umumnya.

Fase pertumbuhan fitoplankton menurut Fauziah dan Hatta (2015) terbagi atas 4 fase. Pada hari pertama kepadatan Tetraselmis sp, tidak meningkat secara signifikan hanya mengalami pertambahan sedikit dari kepadatan awal inokulan. Fase ini disebut sebagai fase adaptasi.

Hal ini sesuai dengan pendapat Armanda (2013), bahwa pada fase istirahat populasi tidak mengalami perubahan, tetapi ukuran sel pada fase ini meningkat. Fotosintesis masih aktif berlangsung dan organisme mengalami metabolisme tetapi belum terjadi pembelahan sel yang menyebabkan kepadatan meningkat. Apabila terjadi perubahan kepadatan, pertambahan terjadi sangat sedikit. MacIntyre, dkk. (2010) menyatakan singkatnya fase lag dipengaruhi oleh besarnya jumlah inokulan, kondisi lingkungan kultur inokulan yang sama dengan kondisi penelitian sehingga menyebabkan daya adaptasi dari mikroalga menjadi cepat. 


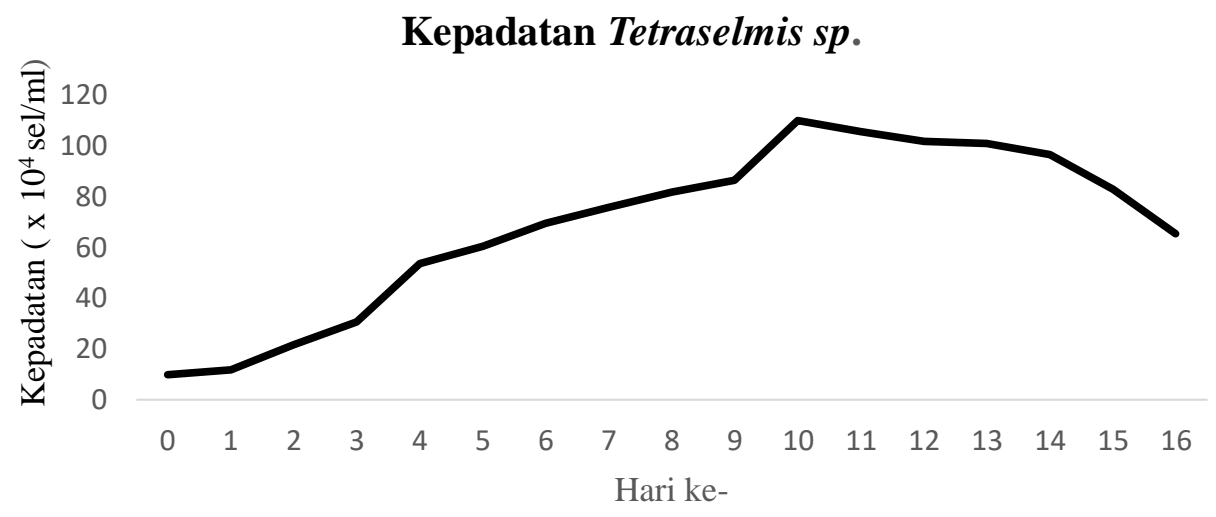

Gambar 1. Rata-Rata Kepadatan Tetraselmis sp. selama pengamatan (ind. $\times 10^{4}$ )

Kepadatan Tetraselmis sp. mulai meningkat pada hari kedua dengan rata-rata kepadatan $21,55 \mathrm{x}$ $10^{4} \mathrm{sel} / \mathrm{ml}$ dan mencapai puncak pada hari kesepuluh dengan rata-rata kepadatan 109,87 x $10^{4} \mathrm{sel} / \mathrm{ml}$. Fase ini disebut sebagai fase pertumbuhan eksponensial (log). Hal ini sesuai dengan pendapat Armanda (2013), bahwa pada fase ini fitoplankton mulai mengalami pembelahan sel dengan laju yang terus meningkat secara signifikan. Wahyuni et al., (2018) menjelaskan, terdapat perbedaan kepadatan dan fase eksponensial pada kultur spirulina $s p$, pada wadah wadah yang berbeda yakni pada hari ke-9 dengan total biomass sebesar $53,375 \times 10^{5} \mathrm{sel} / \mathrm{ml}$ pada wadah kaca dan hari ke-8 pada wadah plastik sebesar $16,993 \times 10^{5}$ sel/ml. Selanjutnya, terjadi fase stasioner dimana tahap pertumbuhan sel yang telah mencapai puncak dan tidak terjadi penambahan jumlah sel lagi sehingga produksi sel pada fase ini tergantung pada kondisi alami dan faktor-faktor yang membatasi pertumbuhan dari mikroalga tersebut (Utomo dkk., 2005). Berdasarkan pengamatan terjadi penurunan kepadatan sel namun tidak menurun secara drastis. Fase ini terjadi selama 3 hari. Menurut Armanda (2013), fase stasioner merupakan saat yang tepat dilakukan pemberian nutrisi sehingga pertumbuhan relatif normal kembali.

Pada hari ke-empat belas terjadi penurunan kepadatan Tetraselmis sp. Fase ini disebut sebagai fase kematian, karena pada fase ini terjadi penurunan jumlah kepadatan fitoplankton. Armanda (2013) berpendapat bahwa pertumbuhan plankton pada saat 
budidaya secara visual dapat ditandai dengan perubahan warna yang awalnya berwarna bening menjadi hijau muda dan berubah lagi menjadi hijau/hijau tua. Perubahan ini disertai dengan menurunnya transparansi.

Hal ini merupakan indikasi dari adanya peningkatan sel yang secara langsung akan berpengaruh kepada tingkat kepadatan. Pertumbuhan fitoplankton sangat mempengaruhi usia panen fitoplankton, dimana pertumbuhan tersebut dapat ditandai dengan perubahan warna kultur, bertambah besarnya ukuran sel atau bertambah banyaknya jumlah sel (Ru'yatin, dkk., 2015).

Kepadatan sel digunakan untuk mengetahui pola pertumbuhan fitoplankton tersebut. Hal ini merupakan indikasi dari adanya peningkatan sel yang secara langsung akan berpengaruh kepada tingkat kepadatan. Pertumbuhan fitoplankton sangat mempengaruhi usia panen fitoplankton, dimana pertumbuhan tersebut dapat ditandai dengan perubahan warna kultur, bertambah besarnya ukuran sel atau bertambah banyaknya jumlah sel (Ru'yatin dkk., 2015).
Selain kepadatan, pemeliharaan kultur juga dilakukan dengan menjaga kualitas fisika, kimia dan biologi lingkungan. Berdasarkan hasil pengamatan rata-rata suhu berkisar antara $23-25^{\circ} \mathrm{C}$ dan termasuk ideal untuk pertumbuhan plankton. Hal ini sesuai dengan pendapat Adi, dkk. (2015) bahwa media kultur Tetraselmis sp. berada pada rentang suhu antara $23-25^{\circ} \mathrm{C}$. Suhu yang rendah dan stabil ini disebabkan oleh kondisi ruangan kultur yang terjaga. Penggunaan AC sangat berpengaruh dalam mempertahankan suhu optimal bagi Tetraselmis sp. khusunya skala laboratorium.

Suhu dipertahankan pada kondisi lebih rendah dibanding suhu ruangan menyesuaikan dengan jenis fitoplankton yang dikultur namun umumnya, suhu laboratorium dipertahankan antara suhu $22-26^{\circ} \mathrm{C}$. Perubahan suhu yang signifikan dapat menyebabkan kematian pada kultur terutama pada spesies fitoplankton yang tidak dapat mentoleransi perubahan kondisi lingkungan yang drastis (Lantang dan Pakidi, 2015). 


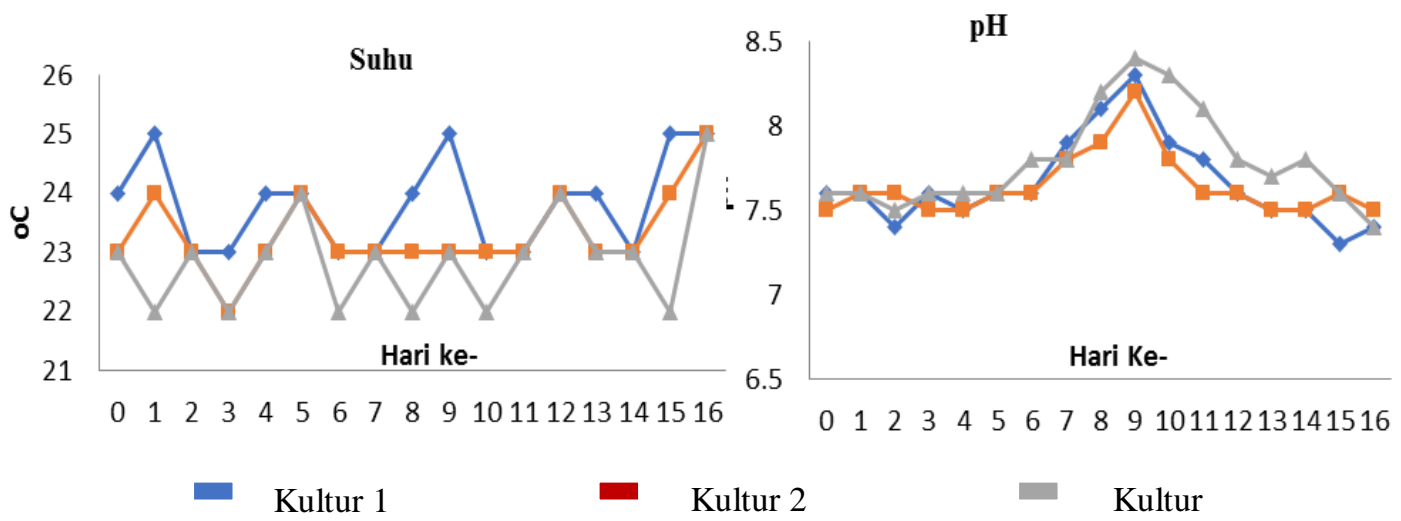

Gambar 2. Hasil pengukuran $\mathrm{pH}$ dan Suhu media kultur Tetraselmis sp.

Faktor lingkungan yang lain adalah salinitas. Salinitas merupakan konsentrasi garam terlarut dalam satuan air. Berdasarkan hasil pengamatan, salinitas kultur Tetraselmis sp. berada pada kisaran 30-31 ppt. Kondisi ini merupakan kondisi yang optimal bagi pertumbuhan Tetraselmis. Hal ini sesuai dengan pendapat Adi, dkk. (2015) bahwa Tetraselmis akan tumbuh secara optimal pada salinitas 30 ppt. Meskipun demikian, Isnansetyo dan Kurniastuty (1995) menjelaskan bahwa alga ini dapat tumbuh pada kisaran salinitas 15-35 ppt. Berubahnya salinitas setelah dilakukan pengenceran diduga disebabkan oleh menguapnya air selama kultur dilakukan. Kondisi ini menyebabkan kadar garam menjadi lebih pekat sehingga salinitas meningkat.
Selain itu, faktor kimia yang menjadi faktor pembatas kepadatan Tetraselmis sp. adalah $\mathrm{pH}$, dimana peningkatan kepadatan tetraselmis $s p$ menyebabkan peningkatan $\mathrm{pH}$ air selama penelitian. Hal ini menunjukan bahwa $\mathrm{pH}$ merupakan indikator konsentrasi ion hidrogen dari aktifitas yang terjadi dalam perairan oleh organisme. Meskipun, selama penelitian kisaran $\mathrm{pH}$ masih dalam kategori optimal yakni berkisar antara 7,4 - 8,4. Hal ini sesuai dengan pendapat Adi, dkk. (2015) bahwa media kultur Tetraselmis berada pada rentang $\mathrm{pH}$ optimum untuk produktivitas perairan, yaitu 7,5 -8,5.

Perubahan salinitas dan $\mathrm{pH}$ yang fluktuatif akan berdampak pada pertumbuhan mikroalga, misalnya transportasi ion-ion, seperti $\mathrm{Na}^{+}$dan $\mathrm{K}^{+}$karena dengan adanya perubahan salinitas dan $\mathrm{pH}$, selektivitas 
permeabilitas membran menjadi berubah yang berakibat pada terganggunya fungsi intraseluler yang berakibat pada pertumbuhan (Kurnianto dan Triandiza., 2012). Selain faktor fisika dan kimia, faktor biologi juga dapat berpengaruh terhadap pertumbuhan kultur. Salah satunya adalah keberadaan kontaminan berupa mikroba pada kultur. Mikroba dapat bersifat merugikan pada kultur yang dipelihara. Selain dapat menjadi ancaman bagi kehidupan Tetraselmis sp., mikroba dapat menjadi kompetitor dalam perolehan oksigen. Sehingga, diperlukan adanya monitoring untuk mencegah adanya kontaminan. Pencegahan dapat dilakukan dengan mensterilkan peralatan yang akan digunakan dengan mencuci dan memberi alkohol.

\section{KESIMPULAN}

Tetraselmis sp. mengalami empat fase hidup seperti fitoplankton pada umumnya yaitu pada hari penebaran bibit hingga hari kedua merupakan fase adaptasi, hari kedua hingga mencapai kepadatan tertinggi pada hari kesepuluh dengan jumlah $109,87 \times 10^{4} \mathrm{sel} / \mathrm{ml}$ merupakan fase eksponensial dan hari berikutnya merupakan fase stasioner dan kematian. Hal yang perlu diperhatikan pada pemeliharaan kultur untuk mempertahankan kondisi pertumbuhan Tetraselmis sp. agar dapat tumbuh optimal diantaranya adalah faktor fisika, kimia dan biologi lingkungan.

\section{DAFTAR PUSTAKA}

Adi, Ida Ayu, A.A.M.D. Anggreni, I.W. Arnata. 2016. Optimasi Salinitas dan $\mathrm{pH}$ Awal Media Bg-11 Terhadap Konsentrasi Biomassa dan Klorofil Tetraselmis chuii. Jurnal Rekayasa dan Manajemen Agroindustri, 3(4): 51-61

Anggraeni, T. D.,. 2016. Teknik Kultur Nitzschia Sp. Dari Skala Laboratorium Sampai Skala Intermediet Di Balai Budidaya Perikanan Air Payau (BPBAP) Situbondo. [Skripsi]. Fakultas Perikanan dan Kelautan. Universitas Airlangga. Surabaya

Armanda, D. T. 2013. Pertumbuhan Kultur Mikroalga Diatom Skeletonema costatum (Grevile) Cleve Isolat Jepara Pada Medium f.2 dan Medium Conway. Bioma. Vol. 2.

Basri S. 2013. Pakan dan pemberian pakan. Kendari: Universitas Haluoleo

Fauziah, F., \& Hatta, M. (2015). Pengaruh Pemberian Kascing (Bekas Cacing) Dengan Dosis Yang Berbeda Dalam Kultur Skeletonema costatum. Acta 
Aquatica: Aquatic Sciences Journal, 2(1): 11-17.

Isnansetyo, A. dan Kurniastuty. 1995. Teknik Kultur Phytoplankton dan Zooplankton. Pakan Alami untuk Pembenihan Organisme Laut. Kanisius. Yogjakarta. Hal 13-97.

Kurnianto, Dedy dan T. Triandiza. 2013. Pengaruh Musim Terhadap Pertumbuhan dan Hasil Rumput Laut (Eucheuma cottoni) yang Ditanam Pada Dua Lokasi Perairan Di Maluku Tenggara. Seminar Nasional Sains dan Teknologi V. Lembaga Penelitian Universitas Lampung. Lampung. 19-20 Nopember 2013.

Lantang, Bonny, C. S. Pakidi. 2015. Identifikasi Jenis Dan Pengaruh Faktor Oseanografi Terhadap Fitoplankton Di Perairan Pantai Payum-Pantai Lampu Satu Kabupaten Merauke. Jurnal Ilmiah Agribisnis dan Perikanan, 8(2): 13-19

McIntyre, H. L., E. Lawrenz, T. L. Richardson. 2010. Taxonomic Discrimination of Phytoplankton by Spectral Fluoroscence. In : Chlorophyll Fluoroscence in Aquatic Science : Methods and Applications. Developments in Applied Phycology 4. Springer Sciences adn Bussines Media B.V.

Rinto, Efendi. 2009. Analisis Kandungan Formalin Pada Ikan Kembung Rebus di Beberapa Pasar Tradisional Kota Medan Tahun 2009.
[Skripsi]. Program Studi Kedokteran Hewan. Fakultas Kedokteran. Universitas Hasanuddin. Makasar.

Ru'yatin, I. S. Rohyani, L. Ali. 2015. Pertumbuhan Tetraselmis dan Nannochloropsis pada Skala Laboratorium. Pros Semnas Masy Biodiv Indon. Vol 1 (2): 296-299

Ruliaty, L., Kholifah, N., Sutanti, E., Apriliyani, S. 2017. Petunjuk Teknis Penyediaan Pakan Alami Udang Jerbung (P. mergueinsis). Direktorat Jendral Perikanan Budidaya Balai Besar Perikanan Budidaya Air Payau Jepara.

Sari, Indah Permata dan A. Manan. 2012. Pola Pertumbuhan Nannochloropsis oculata pada Kultur Skala Laboratorium, Intermediet dan Massal. Jurnal Ilmiah Perikanan dan Kelautan,4(2): 123-127

Satyantini, W. H., E. D. Masithah, M. A. Alamsjah, Prayogo dan S. Andriyono. 2012. Buku Penuntun Praktikum Budidaya Pakan Alami. Fakultas Perikanan dan Kelautan. Universitas Airlangga. Hal 4950.

Supriyantini, E., Ambariyanto, A., \& Widowati, I. (2007). Pengaruh pemberian pakan alami tetraselmis chuii dan skeletonema costatum terhadap kandungan asam lemak omega 6 (asam arakhidonat) pada kerang totok polymesoda erosa the influence of natural food tetraselmis chuii and skeletonema costatum on the profile of the unsaturated fatty acid in marsh clam polymesoda 
erosa. Jurnal Pasir Laut, 3(1): 46-60.

Utomo, N. B. P., Winarti dan A. Erlina. 2005. Pertumbuhan Spirulina platensis Yang Dikultur Dengan Pupuk Inorganik (Urea, TSP dan ZA) dan Kotoran Ayam. Jurnal Akuakultur Indonesia, 4(1): 4148.

Wahyuni, N., Masithah, E. D., Soemarjati, W., Suciyono, S., \& Ulkhaq, M. F. 2018. Pola Pertumbuhan Mikroalga Spirulina sp. Skala Laboratorium yang Dikultur Menggunakan Wadah yang Berbeda. Majalah Ilmiah Bahari Jogja, 16(2): 89-97. 